\title{
KOMPARASI BELAJAR SISWA DALAM MEMECAHKAN MASALAH PERSAMAAN LINEAR MELALUI MODEL PEMBELAJARAN MATEMATIKA REALISTIK INDONESIA
}

\author{
Maria Carmelita Tali Wangge \\ Dosen Program Studi Pendidikan Matematika STKIP Citra Bakti \\ email: carmelitawangge46@gmail.com
}

\begin{abstract}
Abstrak
Kenyataan yang masih sering ditemui adalah masih banyak siswa yang mengalami kesulitan dalam mempelajari matematika. Beberapa penyebab kesulitan tersebut antara lain pelajaran matematika tidak tampak kaitannya dengan kehidupan seharihari, cara penyajian pelajaran matematika yang monoton dari konsep abstrak menuju ke kongkrit, tidak membuat anak senang belajar. Penelitian tentang perbandingan belajar siswa merupakan suatu hal yang penting untuk merencanakan pembelajaran yang sesuai. Tujuan penelitian ini adalah membandingkan cara belajar siswa yang menggunakan model pembelajaran matematika realistik Indonesia dan yang tidak menggunakan model pembelajaran matematika realistik Indonesia. Hasil penelitian menunjukkan bahwa rata-rata hasil belajar siswa pada kelas yang menggunakan model pembelajaran matematika realistik Indonesia berada pada kualifikasi tinggi sedangkan rata-rata hasil belajar siswa pada kelas yang tidak menggunakan model pembelajaran matematika realistik Indonesia pada kualifikasi rendah.
\end{abstract}

\begin{abstract}
The facts that often faced were there were a lot of students who have difficulties in learning Mathematics. Some difficulties reason were learning Mathematics has no relation related to everyday life, the way to presented Mathematics subject was monotonous from abstract concept to concrete, and did not make the students happy to learn. The research about students learning comparison was something important to plan an appropriate learning. This research aimed at comparing how students learned through Realistic Mathematic Indonesian learning model and students who did not learned through Realistic Mathematic Indonesian learning model. The result of research showed that the average of students learning achievement on class which used Realistic Mathematic Indonesian learning model being in high qualification, while that the average of students learning achievement on class which did not use Realistic Mathematic Indonesian learning model being in low qualification.
\end{abstract}

Kata Kunci: Komparasi belajar siswa, PMRI. 


\section{PENDAHULUAN}

IImu

pengetahuan

berkembang seiring dengan teknologi yang semakin maju. Berkembangnya ilmu pengetahuan dan teknologi ini mengakibatkan adanya tuntutan bagi setiap negara untuk meningkatkan kualitas Sumber Daya Manusia (SDM). Indonesia sebagai negara berkembang memiliki jumlah Sumber Daya Manusia yang melimpah. SDM ini perlu ditingkatkan kualitasnya untuk menghadapi persaingan era globaliasi dan pada tahun 2015 Indonesia akan memasuki era ASEAN Free Trade Area (AFTA) atau daerah/kawasan bebas perdagangan, agar tidak tertinggal dari negara lain. Dalam era globalisasi inilah diperlukan SDM handal yang memiliki pemikiran kritis, sistematis, logis, kreatif, dan kemampuan untuk bekerja sama secara efektif. Salah satu lembaga yang dapat menghasilkan SDM seperti itu adalah sekolah. Dan salah satu mata pelajaran yang dapat mengembangkan kemampuan berpikir kreatif adalah matematika.

Tuntutan kurikulum 2013 dan era global pada kegiatan pembelajaran matematika antara lain, adalah menumbuh kembangkan kemampuan pemecahan masalah, melatih berpikir dan bernalar dalam menarik kesimpulan, mengembangkan kreativitas yang melibatkan imajinasi, intuisi dan penemuan melalui pemikiran divergen, orisinal, membuat prediksi, dan mencoba-coba (trial and error), dengan harapan dapat membekali mahasiswa dengan kemampuan berpikir logis, analitis, sistematis, kritis, dan kreatif, serta kemampuan bekerjasama. Kemampuan tersebut diperlukan agar siswa dapat memperoleh, mengelola, dan memanfaatkan informasi untuk menjalani kehidupan sehari-harinya. Sementara materi pelajaran yang tersedia dalam bentuk buku-buku teks, belum mendukung pencapaian tuntutan kurikulum tersebut.

Menurut Supartono (2006:161) kenyataan yang masih sering ditemui adalah masih banyak siswa yang mengalami kesulitan dalam mempelajari matematika. Beberapa penyebab kesulitan tersebut antara lain pelajaran matematika tidak tampak kaitannya 
dengan kehidupan sehari-hari, cara penyajian pelajaran matematika yang monoton dari konsep abstrak menuju ke kongkrit, tidak membuat anak senang belajar. Menurut Rohani (2005:98) siswa belajar matematika tanpa menyadari kegunaannya. Sedangkan menurut Zulkardi (2007:1) ada masalah besar dalam pendidikan matematika di Indonesia. Masalah tersebut adalah kemampuan siswa dalam menyelesaikan suatu problem yang berhubungan dengan kehidupan seharihari masih rendah.

Salah satu pendekatan pembelajaran matematika yang menekankan kegunaan dalam arti khusus, yaitu pembelajaran yang menekankan penggunaan masalah kontekstual sebagai titik awal pembelajaran matematika adalah Realistic Mathematics Education (RME) atau dalam bahasa Indonesia Pembelajaran Matematika Realistik (PMR). PMR kami menyebut pendekatan ini pendekatan sani santun terbuka dan muncul dengan sendirinya tetapi perlu dilatih dan dikembangkan. RME kemudian diadaptasi oleh Indonesia, yang kemudian dinamakan dengan
Pendidikan Matematika Realistik Indonesia (PMRI). Dalam Dikdasmen (2004: 33) prinsip dasar PMRI adalah materi matematika ditransmisikan sebagai aktivitas manusia (human activity), memberi kesempatan siswa menemukan kembali (reinvention) melalui praktek (doing it).

Model pembelajaran PMRI juga merupakan model pembelajaran yang memberikan kesempatan kepada siswa untuk belajar mandiri, kreatif, dan lebih aktif. Model tersebut merupakan model yang menerapkan pemahaman terhadap suatu materi yang dihubungkan dengan kehidupan nyata siswa sehari-hari. Selain itu, PMRI merupakan suatu model pembelajaran matematika yang mengungkapkan pengalaman dan kejadian yang dekat dengan siswa sebagai sarana untuk memahamkan persoalan matematika.

Pembelajaran matematika dengan menggunakan PMRI lebih menekankan kepada "student oriented" atau "problem oriented" sehingga akan mengurangi banyak dominasi guru. Dengan menggunakan pendekatan ini, siswa akan belajar konsep-konsep 
matematika berdasarkan realitas atau lingkungan di sekitar mereka. Hal ini, dimaksudkan agar selama proses pembelajaran berlangsung, siswa yang kurang mampu menemukan alternatif-alternatif pemecahan yang bervariasi dapat menemukan jawaban yang bervariasi dengan mandiri.

\section{Belajar}

Belajar dapat dipahami sebagai tahapan perubahan seluruh tingkah laku yang relatif menetap sebagai hasil pengalaman dan interaksi dengan lingkungan yang melibatkan proses kognitif. Namun demikian perubahan tingkah laku yang timbul akibat proses kematangan, keadaan gila, mabuk, lelah, dan jenuh tidak dapat dipandang sebagai proses.

Belajar dapat dipandang sebagai suatu proses individu, sehingga individu itu mengalami perubahan dalam tingkah lakunya, yaitu lebih baik daripada sebelum belajar. Belajar juga harus mempunyai tujuan yang jelas, yaitu dapat dikusainya beberapa kemampuan intelektual, ketrampilan dan sikap emosional dari siswa. Berhasil atau gagalnya pencapaian tujuan pendidikan itu amat bergantung pada proses belajar yang dialami oleh siswa, baik ketika ia berada di sekolah maupun di lingkungan tempat tinggal siswa yaitu lingkungan keluarga dan masyarakat.

Dalam proses belajar siswa, terdapat faktor-faktor tertentu yang dapat menghambat tercapainya tujuan belajar, yaitu faktor-faktor kesulitan belajar yang dapat dilihat dari menurunnya prestasi belajar siswa atau hal-hal lain yang menyimpang dari kebiasaan siswa. Secara umum faktor-faktor penyebab timbulnya kesulitan belajar siswa (Syah, 2008 : 173) adalah sebagai berikut :

a. Faktor intern siswa

Yaitu hal-hal atau keadaan yang muncul dari dalam diri siswa yang meliputi gangguan atau ketidakmampuan psiko-fisik siswa, seperti rendahnya kapasitas intelegensi siswa, labilnya emosi dan sikap, serta terganggunya alat-alat indera penglihat atau pendengar.

b. Faktor ekstern siswa Yaitu hal-hal atau keadaan yang muncul dari luar diri siswa yang meliputi semua 


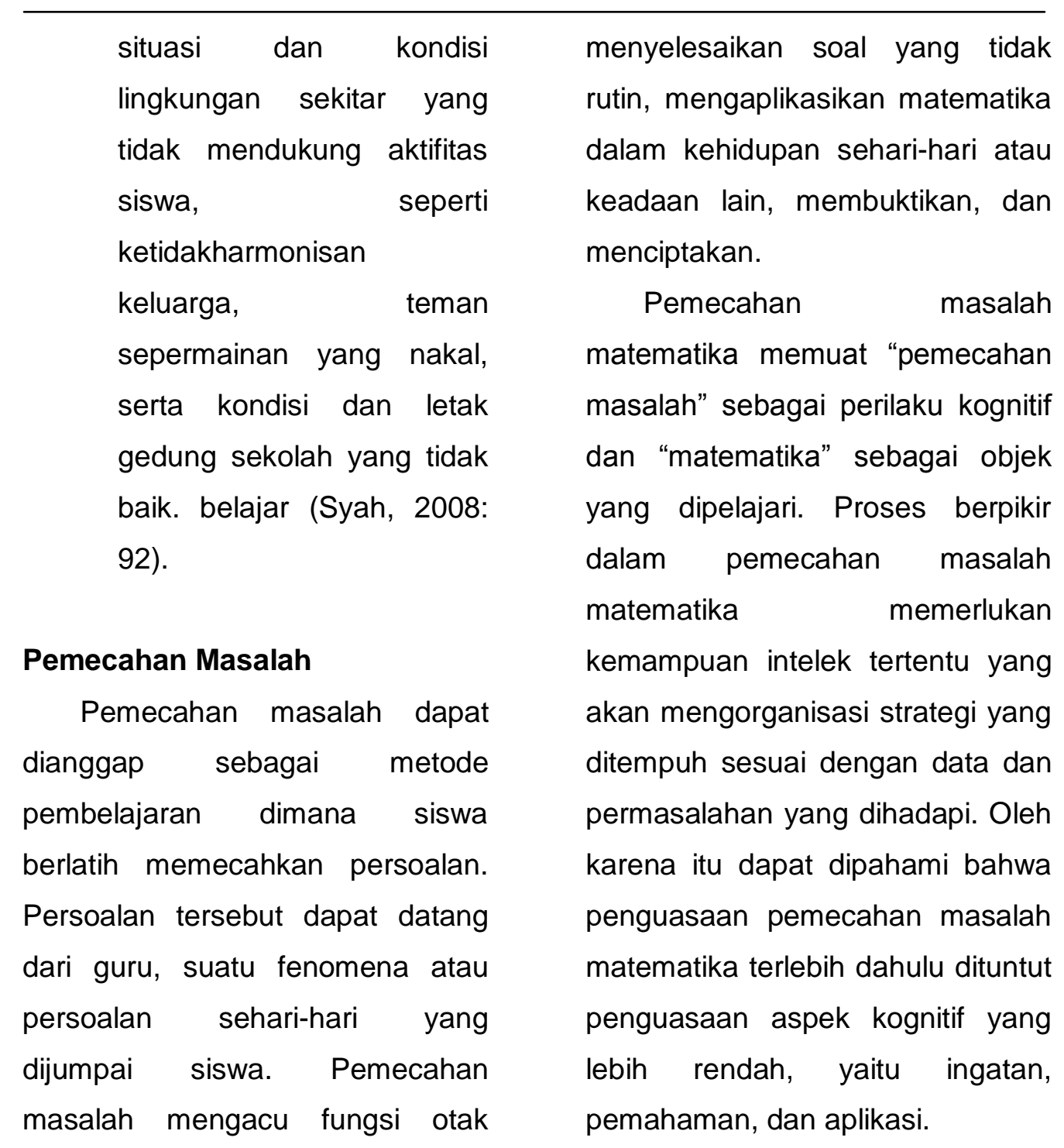

anak, mengembangkan daya pikir secara kreatif untuk mengenali masalah dan mencari alternatif pemecahannya.

Branca menyatakan bahwa istilah pemecahan masalah dapat mempunyai pengertian yang berbeda menurut waktu dan individu. Selanjutnya Branca menyatakan bahwa pemecahan masalah dalam matematika meliputi penyelesaian soal cerita,

\section{Persamaan Linear}

a. Persamaan Linear Satu Variabel

Persamaan linear merupakan sebuah persamaan aljabar dimana tiap sukunya mengandung konstanta atau perkalian konstanta dengan tanda sama dengan serta variabelnya berpangkat satu. Persamaan ini dikatakan linear karena jika kita gambarkan dalam 
koordinat cartesius berbentuk garis lurus. Sistem persamaan linear disebut sistem persamaan linear satu variabel karena dalam sistem tersebut mempunyai satu variabel. Bentuk umum untuk persamaan linear satu variabel yaitu $y=m x+b$ yang dalam hal ini konstanta $m$ menggambarkan gradien garis serta konstanta $b$ adalah titik potong garis dengan sumbu-y.

b. Persamaan Linear Dua Variabel

Jika dalam sistem persamaan linear terdapat dua variabel maka sistem persamaannya disebut sistem persamaan linear dua variabel yang mempunyai bentuk umum $\mathrm{A} x+\mathrm{B} y+\mathrm{C}=0$ dimana bentuk umum ini mempunyai bentuk standar $a x+b y=c$ dengan konstanta $\neq 0$. Dalam mencari titik potong suatu gradien kita gunakan rumus sebagai berikut :

Titik potong dengan sumbu $x$ maka

$$
x=\frac{y}{m}+c,
$$

Titik potong dengan sumbu y maka

$$
y=m x+b
$$

\section{c. PMRI (Pembelajaran}

\section{Matematika Realistik Indonesia)}

Jenning dan Dunne (dalam

Suharta, 2004:1), mengatakan

bahwa kebanyakan siswa mengalami kesulitan dalam mengaplikasikan matematika ke dalam situasi kehidupan real. Menurut sejarahnya RME merupakan suatu pendekatan pembelajaran matematika yang dikembangkan di Belanda sekitar 30 tahun lalu oleh Freudenthal Institute (Streefland, 1991; Gravemeijer, 1994) Di Indonesia, RME disebut Pembelajaran Matematika Realistik (PMR). PMRI adalah adaptasi dari RME (Realistic Mathematics Education) dalam Konteks Indonesia: Budaya, Alam, Sistem Sosial, dll. PMRI mengembangkan suatu teori pembelajaran matematika yang santun, terbuka dan komunikatif. Pendekatan ini dipandang sebagai pendekatan yang banyak memberikan harapan bagi dalam mengaplikasikan matematika ke dalam situasi kehidupan real. Guru dalam pembelajarannya di kelas tidak mengaitkan dengan skema yang telah dimiliki oleh siswa dan siswa kurang diberikan kesempatan untuk menemukan 


kembali dan mengkonstruksi
sendiri
ide-ide
matematika. Menurut Van de
2004:1), bila anak belajar
matematika terpisah dari
pengalaman mereka sehari-hari
maka anak akan cepat lupa dan
tidak dapat mengaplikasikan
matematika.

\section{METODE PENELITIAN}

\section{Rancangan Penelitian}

Penelitian ini menggunakan pendekatan penelitian kuantitatif. Menurut Margono, penelitian kuantitatif adalah suatu proses menemukan pengetahuan yang menggunakan data yang berupa angka sebagai alat menemukan keterangan mengenai apa yang ingin kita ketahui. Penelitian kuantitatif adalah penelitian yang ilmiah yang sistematis terhadap bagian-bagian fenomena serta hubungan-hubunganya.

Pada penelitian kuantitatif separuh dari penelitian adalah proses teori dan proses berteori. Pada proses ini peneliti melakukan analisis-analisis deduktif untuk mencoba menjawab permasalahan yang sedang dihadapi.
Berdasarkan

jenis permasalahan yang dibahas dalam penelitian ini, maka penelitian ini termasuk dalam penelitian komparatif. Dengan desain eksperimen semu, penelitian komparatif adalah penelitian yang akan membandingkan dua variable seperti yang telah dijelaskan oleh Aswarni Sudjud dalam Suharsimi Arikunto bahwa

Penelitian komparasi akan menemukan persamaanpersamaan dan perbedaanperbedaan tentang benda-benda, tentang orang, tentang prosedur kerja, tentang ide-ide, kritik terhadap orang lain, kelompok, terhadap suatu idea tau suatu prosedur kerja. Dapat juga membandingkan kesamaan pandangan dan perubahanperubahan pandangan orang, grup atau Negara, terhadap kasus, terhadap orang, peristiwa atau ideide.

Dalam hal ini yang dibandingkan adalah hasil belajar siswa yang menggunakan pembelajaran matematika realistik Indonesia dan yang tidak menggunakan pembelajaran matematika realistik Indonesia. 


\section{Lokasi Penelitian}

Penelitian ini dilakukan di SMPK Slamet Riyadi Soa, Kecamatan Soa, Kabupaten Ngada.

\section{Populasi dan sampel penelitian}

Populasi dalam penelitian ini adalah seluruh siswa kelas VII SMPK Slamet Riyadi Soa. Sampel pada penelitian ini adalah siswa kelas VIIA dan kelas VIIB.

\section{Metode Pengumpulan Data}

\section{a. Observasi}

Observasi atau pengamatan digunakan dalam rangka mengumpulkan data dalam suatu penelitian, merupakan hasil pembuatan jiwa secara aktif dan penuh perhatian untuk menyadari adanya suatu ransangan tertentu yang diinginkan, atau studi yang sengaja dan sistematik tentang keadaan/fenomena sosial dan gejala-gejala psikis dengan jalan mengamati dan mencatat.

berdasarkan pendapat di atas maka dalam penelitian ini peneliti menggunakan pengamatan langsung terhadap :

1. Lokasi wilayah di SMPK Slamet Riyadi Soa
2. Proses

pembelajaran matematika realistik indonesia di kelas

3. Berbagai hal yang terkait dengan penelitian

b. Dokumentasi

Dokumentasi adalah teknik pengumpulan data yang tidak langsung ditunjukkan pada subjek penelitian, tetapi melalui dokumen. Dokumen merupakan bahan tertulis atau benda mati yang berkaitan dengan suatu peristiwa atau aktifitas tertentu. la bisa berupa rekaman atau dokumen tertulis, seperti arsip data base, surat menyurat, rekaman gambar dan benda-benda peninggalan yang berkaitan dengan suatu peristiwa.

\section{Analisis Data}

Dalam penelitian kuantitatif analisis data meruapakan kegiatan setelah data dari seluruh responden atau sumber data lain terkumpul. Dalam melakukan analisis kuantitatif ini, terdapat suatu proses yang terdiri dari beberapa tahap yang sebaiknya dilakukan. Tahap-tahap tersebut antara lain: 


\section{a. Pengkodean data (data coding)}

Data coding merupakan suatu proses penyusunan secara sistematis data mentah ke dalam bentuk yang mudah dibaca oleh mesin pengelolah seperti komputer.

b. Pemindahan data ke komputer (data entering)

Data entering adalah memindahkan data yang telah diubah menjadi kode kedalam mesin pengolah data.

c. Pembersihan data (data cleaning)

Pembersih data memastikan bahwa seluruh data yang telah dimasukan ke dalam mesin pengolah data sudah sesuai dengan yang sebenarnya. Disini peneliti adalah memerlukan adanya ketelitian dan akurasi data.

Penyajian data (data output)

Penyajian data adalah hasil pengolahan data. Hasil pengolahan data dapat berbentuk sebagai berikut: (1) Numerik atau dalam bentuk angka
Hasil pengolahan data yang berupa numerik dapat disajikan tabel frejuensi dan tabel silang.

(2) Grafik atau dalam bentuk gambar.Penyajian data dengan menggunakan grafik atau gambar lebih menarik jika dibandingkan penyajian data menggunakan tabel frekuensi maupun tabel silang. Namun penyajian data dengan menggunakan gambar atau grafik juga memiliki kelemahan yaitu adanya informasi yang silang.

Penganalisisan data merupakan suatu proses lanjutan dari proses pengolahan data untuk melihat bagaimana menginterpretasikan data, kemudian menganalisis data dari hasil yang sudah ada pada tahap hasil pengolahan data. Sebelum dilakukan uji hipotesis, dilakukan analisis data untuk uji prasyarat yaitu uji homogenitas dan uji normalitas.

Uji Homogenitas

Uji homogenitas digunakan untuk mengetahui apakah kedua kelas yang dibandingkan merupakan akademik yang homogen. Uji ini dilakukan dengan uji $F_{\text {max }}$. 
$\mathrm{F}_{\max }=\frac{\text { variansi_terbesar }}{\text { variansi_terkecil }}$,

$\operatorname{Varian}\left(\mathrm{SD}^{2}\right)=\frac{\sum X 2-\left(\sum X\right) 2 / N}{N-1}$

Tulus Winarsunu menjelaskan bahwa prosedur yang digunakan untuk menguji homogenitas varian dalam kelompok adalah dengan jalan menemukan $F_{\max }$ pada uji homogenitas. Jika $F_{\max } \leq F_{\text {tab }}$ berarti homogen, dan jika $F_{\max } \geq$ $F_{\text {tab }}$ berarti tidak homogen.

Uji Normalitas

Uji normalitas digunakan untuk mengetahui apakah data yang dianalisis berdistribusi normal atau tidak. Jika berdistribusi normal maka dapat dilanjutkan ke uji hipotesis parametric (uji-t), jika tidak normal dilanjutkan ke uji nonparamentric (uji chi-square). Uji normalitas dilakukan dengan bantuan SPSS dengan kriteria signifikasi $\geq 0,05$.

\section{HASIL DAN PEMBAHASAN}

Secara garis besar tujuan penelitian ini adalah membandingkan proses pembelajaran yang menggunakan model pembelajaran matematika realistik indonesia.

Dalam menyampaikan materi, guru sangat jarang mengaitkan materi dengan kehidupan seharihari yang dekat dengan siswa. Akibatnya siswa merasa belajar matematika tidak ada manfaatnya. Begitu juga dalam menyelesaikan soal-soal, guru lebih banyak memberikan petunjuk cara menyelesaikan soal dan mengulang-ulangnya. Dalam menyelesaikan soal setipe, siswa hanya menirukan cara guru tersebut. Hal ini menyebabkan siswa cenderung pasif dalam belajar.

Salah satu alternatif pembelajaran matematika yang mengaitkan pengalaman kehidupan nyata siswa dengan materi serta dapat memberi bekal kompetensi yang memadai baik untuk studi lanjut maupun untuk memasuki dunia kerja adalah pembelajaran matematika realistik indonesia.

\section{Adapun} untuk membandingkan hasil belajar siswa digunakan uji homogenitas dan uji normalitas dimana uji homogenitas ini merupakan uji perbedaan antara dua atau lebih 
populasi. Sedangkan uji normalitas digunakan untuk mengetahui apakah data yang dianalisis berdistribusi normal atau tidak. Jika berdistribusi normal maka dapat dilanjutkan ke uji hipotesis parametric (uji-t), jika tidak normal dilanjutkan ke uji non-paramentric (uji chi-square). Uji normalitas dilakukan dengan bantuan SPSS dengan kriteria signifikasi $\geq 0,05$.

Berdasarkan hasil pembahasan didapatkan nilai signifikansi sebesar 0,873 , nilai signifikansi dari 0,0873>0,005 maka dapat disimpulkan bahwa hasil belajar siswa yang menggunakan model pembelajaran matematika realistik indonesia dan tidak menggunakan model pembelajaran matematika realistik indonesia mempunyai varian yang sama atau homogen.

Sedangkan pada uji normalitas pada hasil pengujian spss, didapatkan nilai yang signifikan dari masing-masig kelas. dimana nilai sign yang diperoleh adalah sebesar $0,079>0,05$, maka kesimpulannya $\mathrm{Ha}$ diterima dan $\mathrm{Ho}$ ditolak artinya distribusi data tersebut diterima.

\section{SIMPULAN DAN SARAN}

\section{Simpulan}

Berdasarkan hasil analisis data dan pembahasan hasil penelitian pembelajaran matematika realistik materi sistem persamaan linear, maka dapat diambil kesimpulan sebagai berikut:

1. Hasil pembahasan didapatkan nilai Signifikansi sebesar 0,873, nilai signifikansi dari $0,0873>0,005$ maka dapat disimpulkan bahwa hasil belajar siswa yang menggunakan model pembelajaran matematika realistik indonesia dan tidak menggunakan model pembelajaran matematika realistik indonesia mempunyai varian yang sama atau homogen.

2. Pada uji normalitas pada hasil pengujian spss, didapatkan nilai yang signifikan dari masing-masig kelas. dimana nilai sign yang diperoleh adalah sebesar 0, $079>0,05$, maka kesimpulannya $\mathrm{Ha}$ diterima dan Ho ditolak artinya distribusi data tersebut diterima.

Adanya perbedaan hasil belajar siswa yang menggunakan model pembelajaran matematika 
realistik indonesia dan tidak menggunakan model pembelajaran matematika realistik indonesia.

\section{Saran}

Berdasarkan hasil penelitian ini, beberapa saran yang dapat peneliti kemukakan sebagai berikut:
a. Pembelajaran matematika realistik dapat digunakan sebagai perangkat pembelajaran alternatif oleh guru untuk mengajar materi persamaan linear.
b. Jika penelitian lain tertarik untuk melakukan penelitian- penelitian yang serupa, maka perlu meminimalisasi kelemahan-kelemahan dalam penelitian ini

\section{DAFTAR PUSTAKA}

Askew, M. (2007). Scaffolding revisited: From tool for result to tool-and-result. In J. Woo, H. Lew, K. Park, \& D. Seo (Eds.), Proceedings of the 31st Conference of the International Group for the Psychology of Mathematics Education (Vol. 2, pp. 3340).Seoul, Korea: The Korea
Society of Educational Studies in Mathematics.

Daphne Robson, 2013. Encouraging students to think strategically when learning to solve linear equations. New Zealand: Journal Of Mathematics

Dikdasmen, 2004. Materi Pelatihan Terintegrasi. Jakarta: Proyek Pengembangan Sistem dan Pengendalian Program

Misdalina, 2009. Pengembangan Materi Integral Untuk Sekolah Menengah Atas (Sma) Menggunakan Pendekatan Pendidikan Matematika Realistik Indonesia (Pmri) Di Palembang. Palembang: JURNAL PENDIDIKAN MATEMATIKA, VOLUME 3, NO. 1

http://kampus.okezone.com/read/2 014/05/13/373/984246/rangki ng-mutu-pendidikan-ri-didunia-paling-jeblok (diakses tanggal 9 Oktober 2014)

Kurikulum 2013 Konsepsi, Implementasi dan Peran Kepala

Sekolah.http://www.ispi.or.id/ 2014/03/23/kurikulum-2013konsepsi-implementasi-danperan-kepalasekolah/(diakses tanggal 9 Oktober 2014)

http://rumusmatematika.com/persamaandan-pertidaksamaan-linear/ 